\title{
PEMETAAN PERSEBARAN FASILITAS UMUM BERBASIS SISTEM INFORMASI GEOGRAFIS (STUDI KASUS DI PROPINSI BENGKULU)
}

\author{
Chandra Yuliansyah ${ }^{1,}$ Harma Oktafia Lingga Wijaya ${ }^{2}$ \\ ${ }^{1}$ Prodi Ilmu Komputer Universitas Pat Petulai, \\ ${ }^{2}$ Prodi Sistem Informasi Universitas Bina Insan, \\ ${ }^{1}$ Email:chandrayuliansyah1987@gmail.com \\ ${ }^{2}$ Email: harmaoktafialingga.univbinainsan.ac.id
}

\begin{abstract}
Abstrak
Propinsi Bengkulu sebagai Propinsi yang sedang menggalakkan sektor pariwisata dengan Semboyan Visit to Bengkulu sangat memerlukan sebuah Sistem Informasi Geografis (SIG) yang dapat membantu pengguna dalam mengakses informasi objek wisata dan fasilitas umum yang diperlkan. Sistem Informasi Geografis (GIS) adalah sistem komputer yang dirancang untuk menangkap, menyimpan, memanipulasi, menganalisis, mengelola, dan menyajikan semua jenis data geografis. Singkatan GIS kadang-kadang digunakan untuk geografis ilmu informasi atau Penelitian informasi geospasial yang berkaitan dengan akademik disiplin atau karir yang bekerja dengan informasi geografis sistem dan domain utama yang lebih luas disiplin akademik geoinformatics. Dengan adanya Sistem Informasi Geografis pemetaan persebaran fasilitas umum di Propinsi Bengkulu ini, dapat memberikan kemudahan bagi masyarakat Propinsi Bengkulu dalam mencari lokasi fasilitas umum yang tersebar di Propinsi Bengkulu dengan mudah dan cepat.
\end{abstract}

\section{Keywords: SIG, GIS, Pemetaan persebaran, fasilitas umum, uml SIG}

\section{PENDAHULUAN}

Propinsi Bengkulu sebagai Propinsi yang sedang menggalakkan sektor pariwisata dengan Semboyan Visit to Bengkulu sangat memerlukan sebuah Sistem Informasi Geografis (SIG) yang dapat membantu pengguna dalam mengakses informasi objek wisata dan fasilitas umum yang diperlkan. Sistem Informasi Geografis (GIS) adalah sistem komputer yang dirancang untuk menangkap, menyimpan, memanipulasi, menganalisis, mengelola, dan menyajikan semua jenis data geografis. Singkatan GIS kadang-kadang digunakan untuk geografis ilmu informasi atau Penelitian informasi geospasial yang berkaitan dengan akademik disiplin atau karir yang bekerja dengan informasi geografis sistem dan domain utama yang lebih luas disiplin akademik geoinformatics [1].

Sistem Informasi Geografis (SIG) memiliki kemampuan yang sangat baik dalam memvisualisasikan data spasial berikut atribut- atributnya, memodifikasi bentuk, warna, ukuran dan simbol yang digabungkan untuk bisa memenuhi kebutuhan pengguna dalam mengakses informasi yang berhubungan dengan lokasi geografis wilayahnya [2]. Perencanaan pembangunan diprioritaskan pada wilayah yang status objek wisata dan pembangunan fasilitas umumnya kurang. Setelah itu ditentukan lokasi pembangunan yang tepat, dengan mempertimbangkan jarak antar objek wisata dan fasilitas umum serta pengaruhnya terhadap objek wisata dan fasilitas umum lain.

Karena lokasi objek wisata dan fasilitas umum tidak diketahui dengan pasti, maka membutuhkan waktu yang lama ketika melakukan perencanaan pembangunan objek wisata dan fasilitas umum. Setiap wilayah harus dianalisis satu per satu untuk melihat objek wisata dan fasilitas umum apa saja yang belum ada di setiap wilayahnya. Dalam merealisasikan Sistem Informasi Geografis ini, penggunaan Google Map API dalam sistem informasi tentunya akan 
menambah fasilitas dari informasi yang disajikan (Sholeh, 2013). Google Maps juga merupakan layanan gratis yang menyediakan peta satelit dan peta hybrid.

Dengan merealisasikan Sistem Informasi Geografis ini, diharapkan bisa membantu permasalahan yang ada di Propinsi Bengkulu serta Visit to Bengkulu berjalan dengan sukses.

\section{METODE PENELITIAN}

Metode SIG yang baik memiliki keserasian antara rencana desain yang baik aturan dunia nyata, di mana metode, model dan implementasi akan berbeda-beda untuk setiap permasalahan. Metode analisis pada GIS pada prinsipnya mendasarkan pada dua hal: Data atribut (ex: jarak dan luas) dan data spasial.

Aliran proses yang digunakan untuk membangun aplikasi Sistem Informasi Geografis adalah dengan menggunakan konsep waterfall yaitu dengan melalui lima tahap yang berkesinambungan membentuk suatu siklus daur hidup.

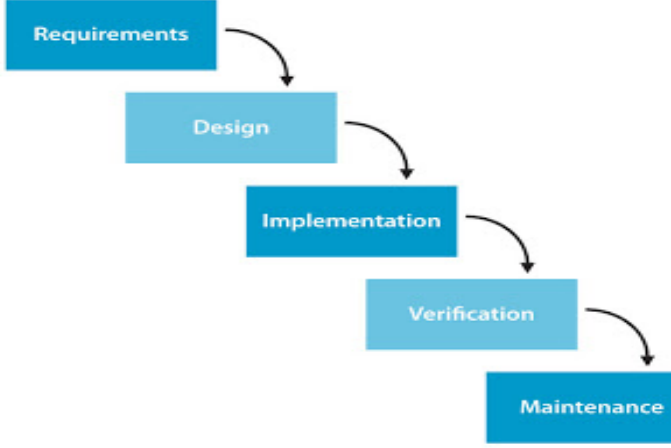

\section{Gambar 1 Model waterfall}

Alur kerja ini merupakan langkah-langkah yang akan dilakukan dalam penyelesaian masalah yang akan dibahas. Secara umum sistimatika yang dimaksud terdapat beberapa langkah yang harus dilakukan dalam penelitian ini seperti pada gambar

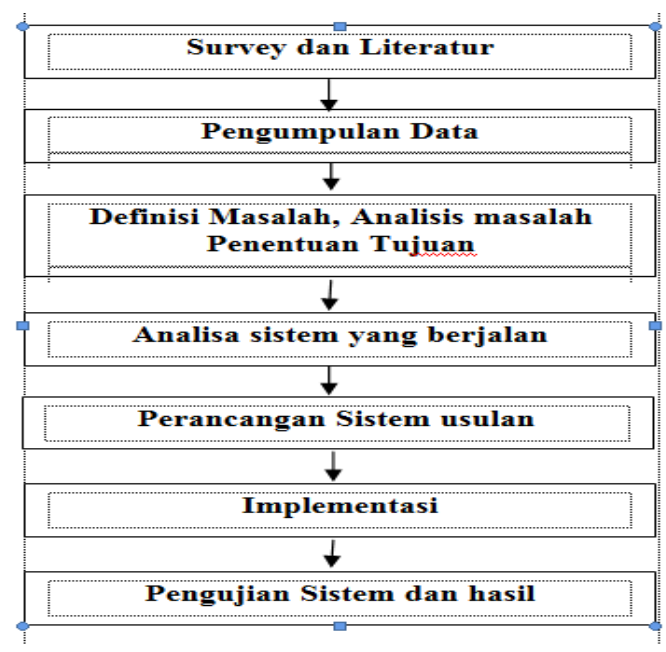

Gambar 2 alur kerja Penelitian

Subjek penelitian ini adalah Pemetaan Persebaran Fasilitas Umum Berbasis Sistem Informasi Geografis studi kasus di Propinsi Bengkulu Sedangkan sistem yang akan dibangun menginformasikan layanan tentang potensi objek wisata dan fasilitas umum dengan menggunakan bahasa pemrograman PHP.

\section{HASIL DAN PEMBAHASAN}

Sistem ini dapat diasumsikan menjadi sebuah sistem yang lebih terintegrasi. Oleh karena itu perancangan sistem yang baru akan lebih dikembangkan menjadi sebuah sistem yang berbasis web. Hasil tersebut dapat memudahkan proses penyampaian informasi letak fasilitas umum yang ada di Propinsi Bengkulu. Informasi yang ditampilkan lebih dinamis dan bisa tepat waktu di saat keadaan tertentu ketika diperlukan dan dukungan berbasis web yang menjadikan informasi data yang dibuat lebih menarik dan bisa dijadikan refrensi dari peneliti lainnya

Use case diagram menjelaskan secara sederhana tentang fungsi sistem. Pada sistem ini use case diagram dibagi menjadi 3 , yaitu admin, user dan pengunjung, di dalam use case diagram admin dan user melakukan login agar admin dan user dapat masuk ke beranda di mana di dalam beranda terdapat beberapa menu yaitu menu beranda, menu kategori, menu jenis,menu fasum,setelah itu user menentukan pilihan fasum mana yang akan dituju lalu user dapat melihat tampilan peta dan narasi dari setiap fasum yang dipilinya. 


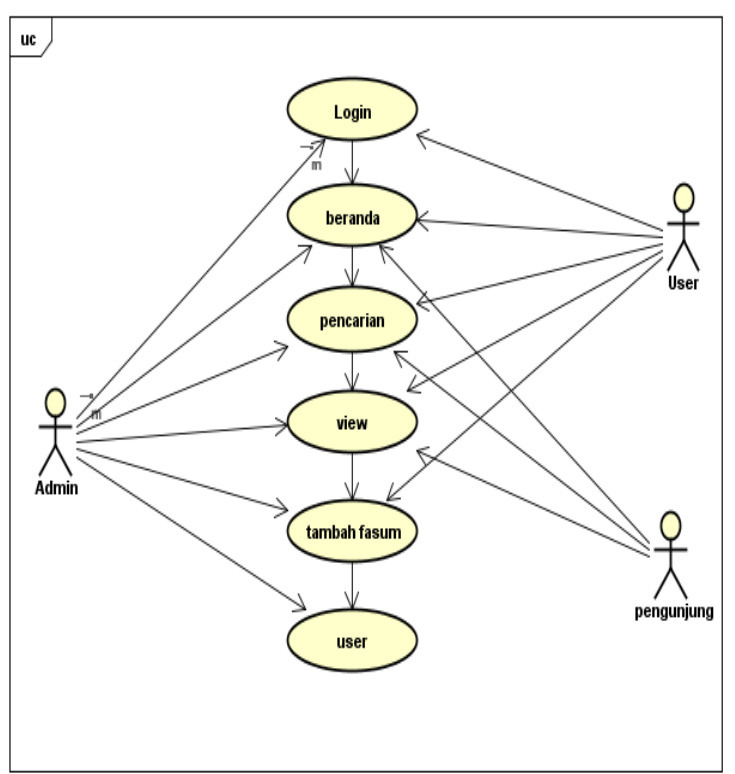

Gambar 3 Use Case Diagram

Antar muka pengguna yaitu tampilan halaman aplikasi sistem yang dapat dilihat oleh user untuk kemudian digunakan dalam mengelola informasi yang ada pada sistem.

\section{a. Tampilan Halaman Login}

Tampilan halaman login sistem merupakan sebuah tampilan awal ketika mengunjungi sistem aplikasi. Pada tampilan halaman login sistem terdapat sebuah form yang berguna untuk menginputkan username dan password untuk dapat masuk ke dalam sistem yang telah disediakan.

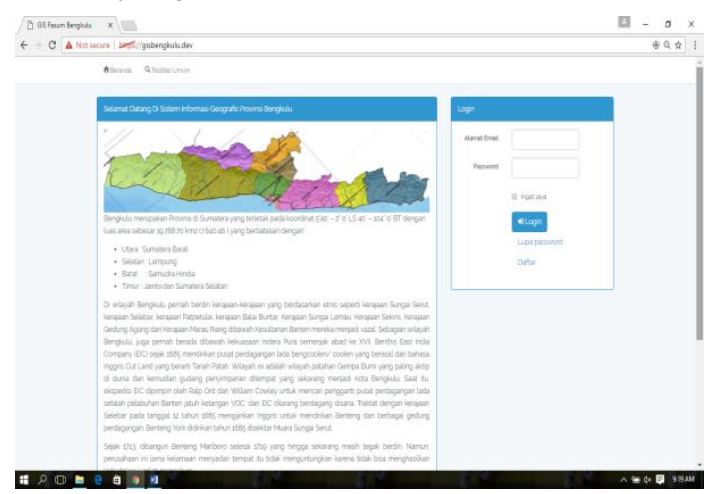

Gambar 4 halaman Login

Tampilan di atas adalah portal masuk login untuk admin yang ingin masuk ke dalam aplikasi website yang sudah dibuat oleh penulis. Admin harus memasukkan username dan password dengan benar, jika salah, peringatan ulang login akan keluar di halaman tersebut

b. Tampilan Halaman Utama Admin

Tampilan halaman utama sistem ini merupakan sebuah halaman yang akan tampil setelah berhasil melakukan login yang selanjutnya digunakan untuk mengelola menu beranda, menu kategori, menu fasum , menu jenis, menu kontak dan menu user ke dalam sistem. Tampilan halaman utama merupakan halaman menu utama admin jika sudah masuk login ke dalam aplikasi web browser pemetaan persebaran fasilitas umum di Propinsi Bengkulu admin akan mengelola semua menu menu yang ada pada halaman aplikasi sehingga admin memiliki peranan yang sangat penting dalam pengelolaan data - data yang berhubungan dengan aplikasi tersebut seperti data fasilitas umum yang ada, kategori dari fasilitas umum , jenis fasilitas umumnya serta menerima komentar dan saran dari user yang menggunakan aplikasi tersebut.

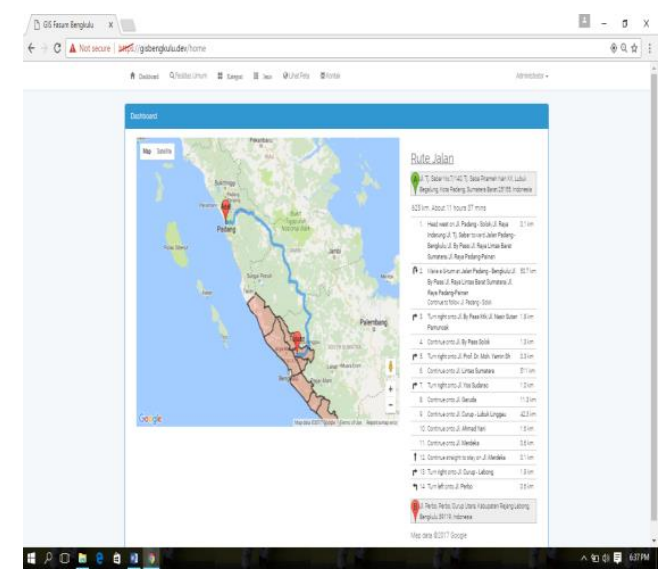

Gambar 5 halaman utama admin

\section{c. Tampilan Interface User Beranda}

Pada halaman ini user dapat melihat profil dari aplikasi website Persebaran Fasilitas Umum di Propinsi Bengkulu, dan dalam hal ini penulis sudah membuat tampilan desainnya berikut ini.

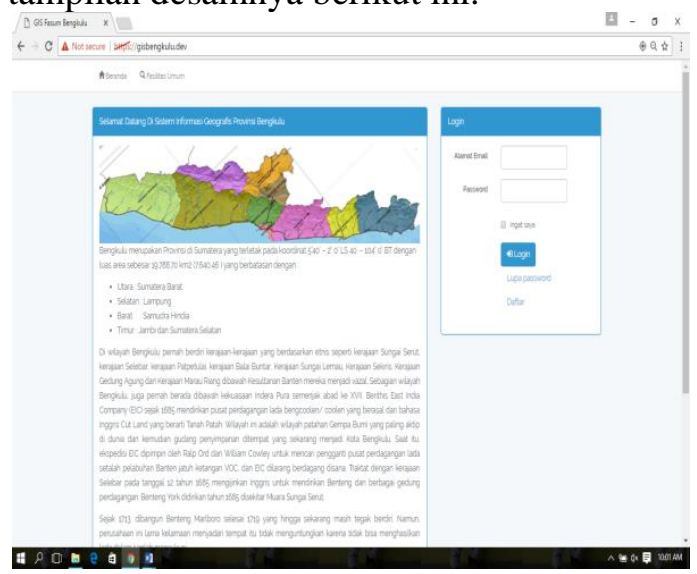

Gambar 6 Interface User Beranda 
d. Tampilan Interface User Fasum

Pada halaman ini user dapat melihat fasum dari aplikasi website Persebaran Fasilitas Umum di Propinsi Bengkulu, di dalam interface user fasum user dapat melakukan pencarian fasilitas umum menggunakan menu pencarian serta user dapat menambahkan fasilitas umum yang belum terdapat di dalam aplikasi pemetaan persebaran fasilitas umum sehingga dengan adanya menu tambah fasum untuk user diharapkan aplikasi ini dapat menjadi alternative lain untuk Propinsi Bengkulu dalam melengkapi kekurangan-kekurangan fasilitas umum yang belum admin survey kelapangan dan sebagai media informasi untuk memperkenalkan kearifan lokal daerah-daerah yang ada di Propinsi Bengkulu kedepannya, untuk itu penulis sudah membuat tampilan desainnya berikut ini.

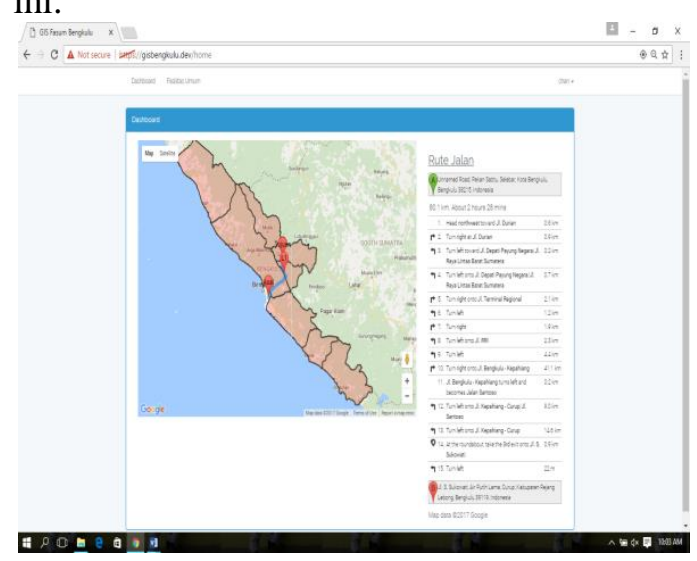

Gambar 7 Tampilan Interface User Fasum

e. Pengujian Sistem

Pengujian secara black box testing merupakan suatu pendekatan untuk menguji apakah setiap fungsi di dalam program dapat berjalan dengan benar, berikut beberapa proses yang dilakukan untuk pengujian sistem melalui tabel pengujian Aplikasi website Pemetaan Persebaran Fasilitas Umum di Propinsi Bengkulu.

Tabel 1 pengujian sistem

\begin{tabular}{|c|l|l|c|}
\hline No & $\begin{array}{l}\text { Rancangan } \\
\text { Proses }\end{array}$ & $\begin{array}{l}\text { Hasil Yang } \\
\text { Diharapkan }\end{array}$ & Hasil \\
\hline 1. & $\begin{array}{l}\text { Mengisi } \\
\text { form login } \\
\text { dan klik } \\
\text { tombol } \\
\text { login }\end{array}$ & $\begin{array}{l}\text { Masuk Sesuai } \\
\text { halaman } \\
\text { utama/Home }\end{array}$ & \\
\hline 2. & Klik menu & Menampilkan & Sesuai \\
\hline
\end{tabular}

\begin{tabular}{|c|l|l|c|}
\hline & Beranda & $\begin{array}{l}\text { menu halaman } \\
\text { beranda }\end{array}$ & \\
\hline 3. & $\begin{array}{l}\text { Klik menu } \\
\text { fasum }\end{array}$ & $\begin{array}{l}\text { Menampilkan } \\
\text { menu halaman } \\
\text { fasum }\end{array}$ & Sesuai \\
\hline 4. & $\begin{array}{l}\text { Klik menu } \\
\text { kategori }\end{array}$ & $\begin{array}{l}\text { Menampilkan } \\
\text { menu halaman } \\
\text { kategori }\end{array}$ & Sesuai \\
\hline 5. & $\begin{array}{l}\text { Klik menu } \\
\text { jenis }\end{array}$ & $\begin{array}{l}\text { Menampilkan } \\
\text { menu halaman } \\
\text { jenis }\end{array}$ & Sesuai \\
\hline 6. & $\begin{array}{l}\text { Klik menu } \\
\text { Kontak }\end{array}$ & $\begin{array}{l}\text { Menampilkan } \\
\text { menu halaman } \\
\text { kontak }\end{array}$ & Sesuai \\
\hline 7. & $\begin{array}{l}\text { Klik menu } \\
\text { User }\end{array}$ & $\begin{array}{l}\text { Menampilkan } \\
\text { menu halaman } \\
\text { user }\end{array}$ & Sesuai \\
\hline 8. & $\begin{array}{l}\text { Klik menu } \\
\text { Beranda }\end{array}$ & $\begin{array}{l}\text { Menampilkan } \\
\text { menu halaman } \\
\text { beranda }\end{array}$ & Sesuai \\
\hline
\end{tabular}

\begin{tabular}{|c|l|l|c|}
\hline No. & $\begin{array}{l}\text { Rancangan } \\
\text { Proses }\end{array}$ & $\begin{array}{l}\text { Hasil Yang } \\
\text { Diharapkan }\end{array}$ & Hasil \\
\hline 9. & $\begin{array}{l}\text { Klik menu } \\
\text { fasum }\end{array}$ & $\begin{array}{l}\text { Menampilkan } \\
\text { menu halaman } \\
\text { fasum }\end{array}$ & Sesuai \\
\hline 10. & $\begin{array}{l}\text { Klik menu } \\
\text { kategori }\end{array}$ & $\begin{array}{l}\text { Menampilkan } \\
\text { menu halaman } \\
\text { kategori }\end{array}$ & Sesuai \\
\hline 11. & $\begin{array}{l}\text { Klik menu } \\
\text { jenis }\end{array}$ & $\begin{array}{l}\text { Menampilkan } \\
\text { menu halaman } \\
\text { jenis }\end{array}$ & Sesuai \\
\hline 12. & $\begin{array}{l}\text { Klik menu } \\
\text { tambah } \\
\text { fasum }\end{array}$ & $\begin{array}{l}\text { Menampilkan } \\
\text { menu halaman } \\
\text { tambah fasum }\end{array}$ & Sesuai \\
\hline 13. & $\begin{array}{l}\text { Fasum } \\
\text { yang } \\
\text { diinginkan }\end{array}$ & $\begin{array}{l}\text { Ditampilkan } \\
\text { pada halaman } \\
\text { pencarian }\end{array}$ & Sesuai \\
\hline
\end{tabular}

Uji coba white box yang penulis lakukan adalah pengujian pada form login admin, jika username atau password salah atau password tidak diisikan maka akan muncul pesan error. Pengujian white box dapat dilihat pada tampilan berikut. 


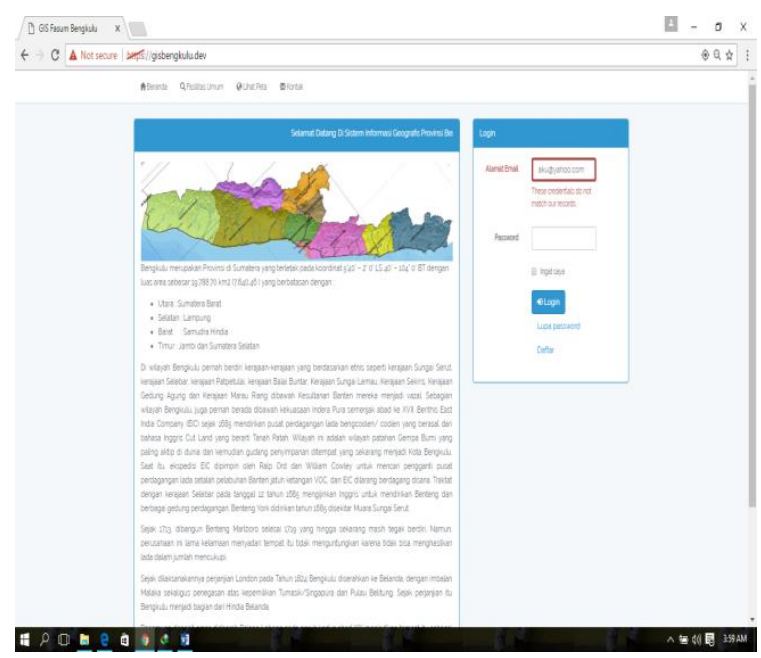

Gambar 8 Halaman White Box Login

Pengujian selanjutnya penulis lakukan pada saat sistem melakukan penginputan koordinat peta secara sembarangan baik latitude maupun longitudenya sehingga untuk menentukan lokasi yang dituju tersebut, sistem memunculkan pesan error yang disebabkan karena koordinat yang diinput tidak dapat dibaca atau koordinat tersebut terlalu jauh.

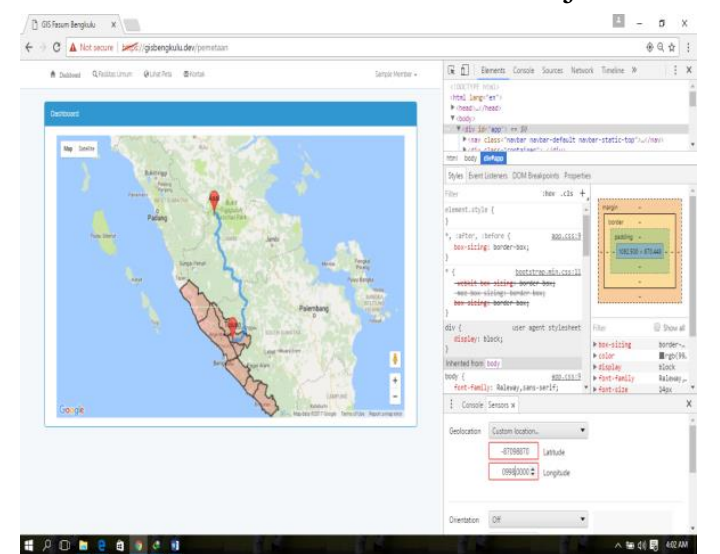

Gambar 9. Mencari Peta Yang Koordinatnya Salah

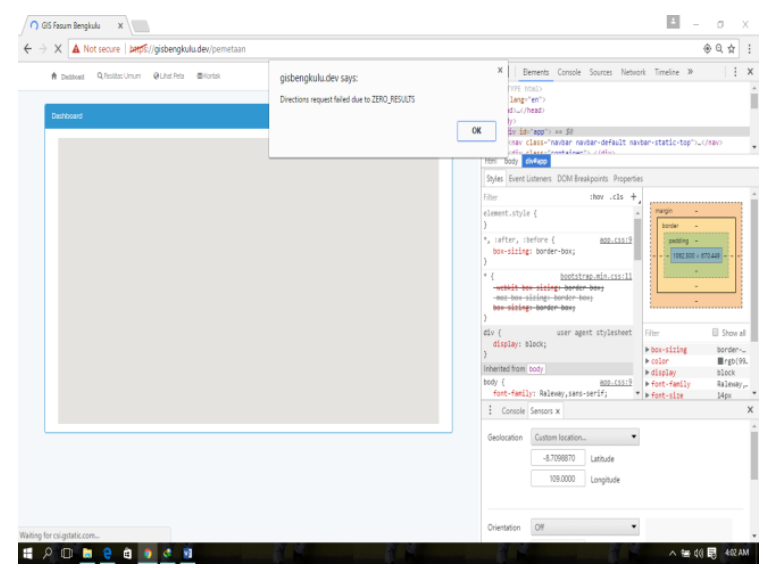

Gambar 10. Mencari Koordinat Yang Terlalu Jauh
Berdasarkan hasil pengujian yang telah dilakukan di atas dapat ditarik kesimpulan bahwa sistem aplikasi website Pemetaan Persebaran Fasilitas Umum di Propinsi Bengkulu dapat berjalan dengan baik dan sesuai dengan yang diharapkan yaitu untuk sarana media penyampaian informasi tentang Pemetaan Persebaran Fasilitas Umum di Propinsi Bengkulu, walaupun terbatasnya hanya pada pengujian yang minimal. Meskipun demikian pengujian yang dilakukan masih terbilang minimal namum diharapkan pengujian yang ditampilkan di atas sudah mewakili pengujian fungsionalitas yang lainnya.

\section{KESIMPULAN}

Setelah melakukan perancangan dan implementasi sistem dalam penelitian ini, maka penulis dapat menarik beberapa kesimpulan yang menjadi keputusan dalam pembuatan aplikasi pemetaan persebaran fasilitas umum di Propinsi Bengkulu tersebut yaitu:

1. Aplikasi sistem informasi geografi pemetaan persebaran fasilitas umum di Propinsi Bengkulu berbentuk aplikasi website ini dapat menghasilkan informasi persebaran fasilitas umum yang ada di Propinsi Bengkulu.

2. Aplikasi pemetaan persebaran fasilitas umum di Propinsi Bengkulu ini dapat mempermudah pemerintah daerah dalam mengelola fasilitas umum yang ada.

3. Aplikasi sistem informasi geografi pemetaan persebaran fasilitas umum ini dapat dijadikan sebagai acuan bagi wisatawan untuk menentukan fasilitas umum dan objek wisata yang akan dikunjungi.

\section{REFERENSI}

[1] Baroš, T., \& Stojanović, T. (2015). Geographic Information System (Gis) In Mapping Of Mine Suspected Area In The Republic Of Serpska. Global Journal of Science Frontier Research: H Environment \& Earth Science, 15(3), 1-5.

[2] Gautama, I. W. W., Putra, I. K. G. D., \& Sukarsa, I. M. ( 2016 ). Aplikasi Pemetaan Objek Wisata Pantai Bali Selatan Berbasis Android

[3] Sholeh, M. (2013). Sistem Informasi Geografis Fasilitas Umum Berbasis Web (Studi Kasus Di Kota Yogyakarta). Paper Presented At The Seminar Nasional Teknologi Informasi Dan Komunikasi. 
[4] Asnawati, \& Kusuma, G. P. (2011). Sistem Informasi Geografis (Sig) Fasilitas - Fasilitas Yang Ada Di Kota Bengkulu Berbasis Web Jurnal Media Infotama, 7(2), 76-102.

[5] Bachtiar, M. A., \& Efendi, R. (2012). Sistem Informasi Geografis Pemetaan Fasilitas Umum Di Kabupaten Sumedang Berbasis Web. Jurnal Ilmiah Komputer Dan Informatika, 1(2), 71-78.

[6] Kharistiani, E., \& Aribowo, E. ( 2013 ). Sistem Informasi Geografis Pemetaan Potensi Sma/Smk Berbasis Web (Studi Kasus : Kabupaten Kebumen) Jurnal Sarjana Teknik Informatika, 1(1), 712-720.

[7] Lestari, R. W., Kanedi, I., \& Arliando, Y. ( 2016 ). Sistem Informasi Geografis (Sig) Daerah Rawan Banjir Di Kota Bengkulu Menggunakan Arcview Jurnal Media Infotama, 12(1), 41-48.

[8] Martin, J., Kumaran, T. V., \& Joseph, R. (2012). Using Geographic Information Systems (Gis) For Spatial Planning And Environmental Management In India: Critical Considerations. International Journal Of Applied Science And Technology, 2, 40-54.

[9] Redjeki, S., Guntara, M., \& Pius, A. ( 2014). Perancangan Sistem Identifikasi Dan Pemetaan Potensi Kemiskinan Untuk Optimalisasi Program Kemiskinan

[10] Susanti, E., \& Andayati, D. ( 2014). Web Sig (Sistem Informasi Geografis) Untuk Fasilitas Umum (Studi Kasus Di Kota Yogyakarta) Paper Presented At The Seminar Nasional Aplikasi Sains \& Teknologi (Snast) 2014, Yogyakarta. 